Надія Височіна,

доктор наук з фізичного виховання і спорту

Навчально-науковий інститут фізичної культури та спортивно-оздоровчих технологій

Національного університету оборони України імені Івана Черняховського, м. Київ

ORCID ID 0000-0001-6098-9699

Лариса Гуніна, доктор біологічнихнаук, професор Олімпійський інститут Національного університету фізичного виховання і спорту України, м. Київ

ORCID ID 0000-0002-6207-1117

Лідія Котляренко, доктор біологічних наук, професор

Навчально-науковий інститут фізичної культури та спортивно-оздоровчих технологій Національного університету оборони України імені Івана Черняховського, м. Київ

ORCID ID 0000-0001-5237-8564

Ольга Малахова,

Навчально-науковий інститут фізичної культури та спортивно-оздоровчих технологій Національного університету оборони України імені Івана Черняховського, м. Київ

ORCID ID 0000-0002-9227-9234

Олена Кириченко, військова частина А0136 Збройних Сил України, м. Київ ORCID ID 0000-0002-0019-9895

DOI: $10.33099 / 2617-1775 / 2020-02 / 59-75$

\title{
ТЕОРЕТИКО-МЕТОДИЧНІ ПЕРЕДУМОВИ ФОРМУВАННЯ СИСТЕМИ РУКОПАШНОЇ ПІДГОТОВКИ ВІЙСЬКОВОСЛУЖБОВЦІВ- ЖІНОК ІЗ УРАХУВАННЯМ ДОСВІДУ КРАЇН БЛОКУ НАТО
}

\footnotetext{
Розглянуто актуальну проблему формування військово-прикладних навичок рукопашного бою військовослужбовиів-жінок (на прикладі курсанток старших курсів Національної академіі Національної гвардії України). У відповідності до моніторингу науково-методичної та спеціальної літератури в обраному напрямі дослідження визначено основні блоки майбутньої змістово-функціональної моделі рукопашної підготовки курсанток в системі їх професійної освіти. Вважаємо, щьо під час формування навичок застосування заходів фізичного впливу військовослужбовиями-жінками ЗСУ та НГУ конче необхідно враховувати фізіологічні, психофізичні та індивідуально-типологічні особливості жіночого організму, щз забезпечить розвиток стійких професійних компетентностей (навичок ведення рукопашної сутички).

Ключові слова: військовослужбовиі-жінки; майбутні офіиери; професійна підготовка; система рукопашної підготовки; спеціальна фізична підготовка; технічний арсенал; нові стандарти.
} 
Постановка проблеми. На сьогодні в Україні відбувається інтеграція до європейського та світового співтовариства, яка не оминає й силові структури та спеціальні служби України, зокрема, Збройні Сили України (ЗСУ) та Національну гвардію України (НГУ). Варто зауважити, що виконання завдань за призначенням військовослужбовцями ЗСУ та НГУ відбувається у різних умовах службово-бойової діяльності, нерідко екстремальних, що вимагає від них високої професійної підготовленості (компетентностей), адже завдання які вони виконують забезпечують мир та спокій в Україні.

Система професійної підготовки у ЗСУ та НГУ передбачає вивчення військовослужбовцями різних дисциплін, які спрямовані на формування необхідних професійних компетентностей. Основними предметами бойової підготовки (професійної підготовки) є: тактична підготовка, вогнева підготовка та фізична підготовка, яка має спеціальну спрямованість. Слід підкреслити, що саме фізична підготовка забезпечує готовність військовослужбовців до виконання завдань за призначенням, адже неможливо виконати бойові завдання без значних фізичних зусиль, що підкреслює актуальність всебічного фізичного розвитку представників силових структур та спеціальних служб України.

Крім цього, в системі фізичної підготовки військовослужбовці ЗСУ та НГУ під керівництвом фахівців у сфері фізичної підготовки і спорту формують навички службово-прикладного рукопашного бою. Важливим є той факт, що саме службово-прикладний рукопашний бій, як домінантний та складнокоординаційний розділ фізичної підготовки, забезпечує формування у військовослужбовців ЗСУ та НГУ необхідних професійних компетентностей (психофізичних якостей), які $€$ важливими для виконання завдань за призначенням у різних умовах службово-бойової діяльності (СБД).

Однак варто зауважити, що на сьогодні організація практичних занять 3 рукопашного бою в системі професійної підготовки військовослужбовців ЗСУ та НГУ здійснюється без урахування індивідуально-типологічних (психофізіологічних) особливостей військовослужбовців-жінок, що знижує ефективність навчального процесу й відповідним чином - їх професійний рівень (прикладні професійні компетентності). Позиції, зазначені вище, негативно впливають на загальний рівень бойової готовності підрозділів, що потребує внесення відповідних змін до програм професійної підготовки військовослужбовців, в цілому, та, урахуванням гендерної складової, військовослужбовців-жінок, зокрема, і обгрунтовує актуальність обраного напряму дослідження.

Також важливим $є$ той факт, що у військових частинах ЗСУ та НГУ практичні заняття з фізичної підготовки, проведення форм фізичної підготовки, а зокрема - практичних занять 3 рукопашного бою (застосування заходів фізичного впливу) забезпечується безпосередньо командирами підрозділів (офіцерами). Актуальною $є$ також уніфікація у загальному вигляді навчальних програм з фізичного виховання та методики фізичної підготовки (спеціальної фізичної підготовки) майбутніх офіцерів - командирів підрозділів - відповідно до вимог сьогодення, проте, це потребує врахування гендерних фізіологічних та 
психофізіологічних особливостей осіб жіночої статі. У свою чергу, під час трансформації системи фізичної підготовки курсантів вищих військових навчальних закладів ЗСУ та НГУ доцільним є урахування наявного бойового досвіду та досвіду професійної підготовки країн блоку НАТО.

Використання новітніх педагогічних технологій (методик) під час практичних занять з рукопашного бою із майбутніми офіцерами жіночої статі, що пов'язують свою діяльність зі службою у лавах ЗСУ та НГУ, під час їх професійного становлення забезпечить набуття ними необхідного рівня готовності (професійних компетентностей) до виконання завдань за призначенням та $€$ актуальним напрямом наукових досліджень.

Дослідження виконано відповідно до плану науково-дослідної роботи i дослідно-конструкторських робіт наступних підрозділів: науково-дослідної лабораторії наукового супроводження розроблення нормативів і стандартів фізичної підготовки і спорту науково-дослідного центру проблем фізичного виховання, спеціальної фізичної підготовки і спорту Навчально-наукового інституту фізичної культури та спортивно-оздоровчих технологій Національного університету оборони України імені Івана Черняховського (2019-2020 p.p.).

Аналіз останніх досліджень і публікацій. Висвітлення актуальних питань удосконалення військово-прикладних навичок рукопашної підготовки військовослужбовців ЗСУ та НГУ, представників інших силових структур і спеціальних служб України в системі їх професійної (службової) підготовки присвячено роботи: Антоненка С.А., Журавля О.В., Любчича Р.І., Максимчука Б.А., Малолєпшего С.Б., Молокова О.В., Моргунова О.А., Пристинського О.В., Романчука С.В., Хацаюка О.В., Чуха А.М., Ярещенка О.А. та інших фахівців із зазначеного напряму. Вище перелічені вчені (водночас - досвідчені тренери із різних службово-прикладних єдиноборств), що працюють у силових структурах та спеціальних службах України, у своїх наукових та науково-методичних працях акцентують увагу на прикладній спрямованості застосування заходів фізичного впливу підлеглим особовим складом під час безпосереднього виконання завдань за призначенням. Однак більшість напрацювань у цій сфері не відповідають реаліям сьогодення, що потребує відповідної трансформації відповідно до набутого бойового досвіду та вимог гендерної рівності та гендерної особистості.

Дослідження структуроване упродовж трьох етапів (вересень 2019-травень 2020 р.р.). Проведений на першому етапі дослідження (вересень 2019-січень 2020 р.р.) аналіз результатів науково-методичної, спеціальної літератури та інтернет-ресурсів з напряму рукопашної підготовки військовослужбовців-жінок (жінок-поліцейських) дозволив виявити ряд наукових праць вчених, а саме: Міхоніна А.А., Циганка А.О., Буздова А.Ю. [1], Романчука С.В. [2], Малолєпшого С.Б., Калюжного М.Г., Хацаюка О.В. [3], Картамишева Д.А. [4], Радченка Ю.А. [5], Сухоради Г.І., Тверитньова В.І., Філіна В.Г. [6]. Варто зауважити, що у зазначених вище роботах система рукопашної підготовки 
військовослужбовців-жінок висвітлена не в повному обсязі, що потребує подальших наукових розвідок.

У свою чергу, в роботах: Соколової О.П. [7], Боярчука О.М. [8], Тьорло О.І. [9], Пічугіна М.Ф., Грибана Г.П., Романчука В.М. [10], Фільгіної Е.В., Савича Д.М. [11], Кириченка О.М. [12] та інших провідних вчених i практиків - Боровика М.О., Гавроника В.І., Горлова А.С., Карасьова А.В., Сорокіна В.П., Таймасова Ю.І., Турчинова А.В., Мещерякова С.П. - викладено окремі складові системи фізичної підготовки військовослужбовців-жінок. Зазначені вище напрацювання $є$ корисними у практичному сенсі та можуть бути теоретико-методичними підвалинами для побудови багаторівневої системи формування навичок рукопашної підготовки військовослужбовців-жінок, зокрема, курсанток ВВНЗ України.

Цікавими за своїм змістом та науковою новизною є роботи: Кондратьєвої А.В. [13], Земцової І.І., Мусаханова З.А., Височіної Н.Л., Станкевич Л.Г. [14], Сімакової Е.А. [15], Височіної Н.Л. [16], Головащенка Р.В., Кузьменка М.В., Гуніної Л.М., Носач О.В. [17], Хуртенка О.В., Білошицького В.В., Власка С.В., Партики С.С., Коновалова Д.О. [18], Шемчука В.А., Дмитренко С.М., Климовича В.Б., Хуртенко О.В., Курбакової С.В. [19] (та інших : Близнюк А.А., Бугаєвського К.А., Лисиціна В.В., Омарової П.Г., Султанова Р.А., Тіхонової І.В., Уляєвої П.Г.), в яких розкриваються техніко-тактичні (психофізіологічні) та загальнобіологічні особливості функціональних змін протягом підготовки спортсменок-єдиноборців до змагань різних рангів у системі їх багаторічної підготовки. Зазначені вище наукові праці є корисними для впровадження у систему рукопашної підготовки курсанток ВВНЗ (військовослужбовців-жінок).

Моніторинг діючих нормативно-правових документів [20, 21], програм підготовки курсантів ВВНЗ - НГУ [22], ЗСУ [23] - зі спеціальної фізичної підготовки (фізичного виховання та методики фізичної підготовки) у напряму вдосконалення техніки та тактики застосування навичок рукопашного бою у різних умовах службово-бойової діяльності свідчить про те, що на сьогодні у джерелах спеціальної літератури не повною мірою відображено всі необхідні складові системи рукопашної підготовки, що потребує додаткових досліджень та внесення відповідних коректив у нормативно-правові документи та освітні програми професійної підготовки майбутніх офіцерів.

Резюмуючи результати першого етапу дослідження, можна зробити висновок, що, не дивлячись на значну кількість робіт з обраного нами напряму дослідження, проблему формування системи рукопашної підготовки військовослужбовців-жінок із урахуванням сучасного досвіду країн блоку НАТО висвітлено недостатньо, що потребує подальших наукових напрацювань.

Мета статті. Головною метою цієї роботи $є$ побудова підходів до формування системи визначення основних складових військово-прикладних навичок рукопашного бою курсанток вищих військових навчальних закладів силових структур України в системі їх професійної освіти із урахуванням даних існуючої літератури та досвіду бойової підготовки країн блоку НАТО. 
Для досягнення мети дослідження планувалося вирішити наступні завдання:

- здійснити аналіз науково-методичної та спеціальної літератури (інтернетресурсів) у напрямах: рукопашної підготовки військовослужбовців-жінок (жінок-поліцейських); системи фізичної підготовки військовослужбовців-жінок (жінок-поліцейських);

- провести аналіз спеціальної літератури у напрямі всебічної підготовки спортсменок-єдиноборців в системі їх багаторічної підготовки;

- здійснити аналіз діючих нормативно-правових документів, програм підготовки майбутніх офіцерів ЗСУ та НГУ зі спеціальної фізичної підготовки у напрямі удосконалення техніки та тактики застосування навичок рукопашного бою у різних умовах службово-бойової діяльності;

- провести теоретичний аналіз стандарту бойової підготовки військовослужбовців армії США (ТC 3-25.150 «Combatives» [24]) та визначити ефективний технічний та тактичний арсенал службово-прикладного рукопашного бою, який доцільно впровадити у систему рукопашної підготовки курсанток ВВНЗ (військовослужбовців-жінок) силових структур і спеціальних служб України;

- здійснити моніторинг науково-методичної літератури в напряму розроблення сучасних педагогічних моделей формування готовності фахівців до професійної діяльності;

- визначити основні компоненти майбутньої змістово-функціональної моделі рукопашної підготовки курсанток ВВНЗ в системі їх професійної освіти.

Методи дослідження: аналіз та узагальнення результатів спеціальної навчально-методичної та науково-методичної літератури і відповідних напряму дослідження інтернет-ресурсів.

Виклад основного матеріалу.3 метою якісного відпрацювання завдань та досягнення мети дослідження було створено науково-дослідну групу, до складу якої увійшли провідні учені та практики із зазначеного вище напряму: Височіна Н.Л., Хацаюк О.В., Гуніна Л.М., Котляренко Л.Т., Федоренко О.О., Кириченко O.M.

Відповідно до побудованої нами структури дослідження на другому етапі (лютий-березень 2020 р.) та поставлених завдань нами проведено теоретичний аналіз стандарту бойової підготовки військовослужбовців армії США (ТС 325.150 «Combatives» [24]) та визначено ефективний техніко-тактичний арсенал службово-прикладного рукопашного бою, що доцільно впровадити у систему рукопашної підготовки курсанток ВВНЗ (військовослужбовців-жінок різних силових структур та спеціальних служб України).

Для підтвердження наявності чи відсутності науково-педагогічної проблеми проведено порівняльний аналіз нормативно-правових документів, які регламентують порядок формування навичок рукопашної підготовки у військовослужбовців-жінок НГУ [20 с. 42-54, 111-118], ЗСУ [21 с. 24-26, 81-87] та США [24] (результати порівняльного аналізу викладено у табл. 1).

Відповідно до результатів, наведених у табл. 1, членами науково-дослідної 
групи визначено основний техніко-тактичний арсенал, який відсутній в програмах спеціальної фізичної підготовки військовослужбовців-жінок (ЗСУ, НГУ), який необхідно врахувати під час подальшого розроблення програми рукопашної підготовки курсанток ВВНЗ (ЗСУ, НГУ) в системі їх професійної освіти. Варто зауважити, що зазначені у табл. 1 техніко-тактичні складові рукопашної підготовки повинні відпрацьовуватися курсантками ВВНЗ (ЗСУ, НГУ) iз урахуванням фізіологічних та індивідуально-типологічних особливостей жінок, що забезпечить стійке формування військово-прикладних навичок рукопашного бою.

\section{Порівняльний аналіз техніко-тактичного арсеналу службово-прикладного рукопашного бою військовослужбовців-жінок ЗСУ, НГУ та США}

Таблиця 1

\begin{tabular}{|c|c|c|c|c|}
\hline \multirow[t]{2}{*}{$\begin{array}{l}\text { No } \\
3 / \text { II }\end{array}$} & \multirow[t]{2}{*}{$\begin{array}{c}\text { Техніко-тактичний арсенал } \\
\text { службово-прикладного рукопашного бою }\end{array}$} & \multicolumn{3}{|c|}{$\begin{array}{c}\text { Керівні документи, які } \\
\text { регламентують формування } \\
\text { навичок рукопашної підготовки } \\
\text { у силових структурах: }\end{array}$} \\
\hline & & НГУ [20] & 3СУ [21] & США [24] \\
\hline 1. & Тактичні пересування в положення лежачи & - & - & + \\
\hline 2. & Прийоми самозахисту в положенні лежачи & - & - & + \\
\hline 3. & Визволення від захватів у партері & - & - & + \\
\hline 4. & Обеззброєння супротивника в положенні лежачи & - & - & + \\
\hline 5. & Конвоювання двома та більше військовослужбовцями & - & - & + \\
\hline 6. & Тактика застосування технічного арсеналу у стійці & - & - & + \\
\hline 7. & $\begin{array}{l}\text { Тактико-технічні складові ведення рукопашної } \\
\text { сутички в партері }\end{array}$ & - & - & + \\
\hline 8. & Використання контрприйомів у стійці & - & - & + \\
\hline 9. & Використання контрприйомів в положенні лежачи & - & - & + \\
\hline
\end{tabular}

Під час поглиблення дослідження нами було визначено ефективність техніко-тактичного арсеналу службово-прикладного рукопашного бою військовослужбовців-жінок армї США порівняно 3 напрацюваннями, що використовуються представницями ЗСУ та НГУ. Результати порівняльного дослідження викладено у табл. 2.

Варто підкреслити, що визначення ефективності застосування технікотактичного арсеналу військовослужбовцями-жінками армії США (див. табл. 2) здійснено методом експертної оцінки за десятибальною шкалою. До складу експертної комісії залучено провідних тренерів-дослідників зі службовоприкладних видів єдиноборств силових структур та спеціальних служб України $(\mathrm{n}=12$ осіб$)$. 
Порівняння ефективного техніко-тактичного арсеналу службово-прикладного рукопашного бою військовослужбовців-жінок армії США (стандарт ТС 3-25.150 «Combatives») та військовослужбовців-жінок НГУ [20] та ЗСУ [21]

\begin{tabular}{|c|c|c|}
\hline $\begin{array}{l}\text { № } \\
\text { 3/II }\end{array}$ & $\begin{array}{c}\text { Техніко-тактичний арсенал } \\
\text { службово-прикладного рукопашного бою }\end{array}$ & $\begin{array}{c}\text { Ефективність } \\
\text { (за 10- } \\
\text { бальною } \\
\text { шкалою), } \\
\text { бали }\end{array}$ \\
\hline \multicolumn{3}{|c|}{ І. Технічні дії у стійці } \\
\hline 1.1 & Акцентування уваги на захватах рук, зачепів ногами & 6,3 \\
\hline 1.2 & Контроль дистанції до супротивника у стійці & 9,1 \\
\hline 1.3 & Використання ударів головою (шоломом) & 10 \\
\hline 1.4 & $\begin{array}{l}\text { Урахування біомеханічних особливостей під час виведення } \\
\text { супротивника із рівноваги }\end{array}$ & 7,3 \\
\hline \multicolumn{3}{|c|}{ ІІ. Технічні дії в положенні лежачи (партері) } \\
\hline 2.1 & $\begin{array}{l}\text { Положення приготування до бою в упорі на одне коліно, готовність } \\
\text { до ведення сутички (ведення вогню) лежачи }\end{array}$ & 10 \\
\hline 2.2 & $\begin{array}{l}\text { Акцентування на здійснення контролюючих захватів руками, ногами } \\
\text { в положенні лежачи }\end{array}$ & 9,4 \\
\hline 2.3 & Використання ударної техніки в партері (кулаками, ліктями) & 8,7 \\
\hline 2.4 & Використання ударів головою (шоломом) в положенні лежачи & 9,1 \\
\hline 2.5 & $\begin{array}{l}\text { Ефективне застосування техніки та тактики уходів } 3 \text { больових } \\
\text { прийомів, утримання та спроб задушення }\end{array}$ & 10 \\
\hline 2.6 & Удари ногами, колінами в партері & 9,1 \\
\hline \multicolumn{3}{|c|}{ III. Тактичні дії (ефективні комбінації фізичного впливу на супротивника) } \\
\hline 3.1 & $\begin{array}{l}\text { Взаємодопомога під час затримання супротивника та ведення } \\
\text { рукопашної сутички із переважаючим за силою супротивником }\end{array}$ & 10 \\
\hline 3.2 & $\begin{array}{l}\text { Використання ефективних техніко-тактичних комбінацій під час } \\
\text { затримання супротивника, який знаходиться в транспорті }\end{array}$ & 7,4 \\
\hline
\end{tabular}

Відповідно до вищевикладеного, можливим є визначення інших складових, які позитивно впливають на формування навичок службово-прикладного рукопашного бою військовослужбовців-жінок армії США, що дозволяє удосконалити систему рукопашної підготовки курсанток ВВНЗ ЗСУ та НГУ (так само як військовослужбовців-жінок інших силових структур та спеціальних служб України). Так, під час практичних занять (тренінгів) 3 рукопашного бою в системі бойової підготовки військовослужбовців-жінок армії США акцентується увага на суворому дотриманні заходів попередження травматизму та особистої безпеки. 3 цією метою широко використовуються якісні та безпечні макети зброї, а також різноманітне захисне екіпірування. Крім цього, система рукопашного бою, яка викладена у стандарті бойової підготовки військовослужбовців армії США [24], грунтується на застосуванні технічного арсеналу наступних видів єдиноборств: вільної боротьби, крав-маги, змішаних бойових мистецтв, що акцентує нашу увагу на впровадженні зазначених бойових дисциплін у секційну роботу курсанток ВВНЗ.

Разом $з$ тим, не дивлячись на якісне викладення особливостей технічного 
та тактичного виконання прийомів рукопашного бою військовослужбовцямижінками армії США (зазначеного у стандарті бойової підготовки ТС 3-25.150 «Combatives» [24]), вважаємо, що у розділі «обеззброєння супротивника, озброєного ножем», не доцільним є здійснення контакту (захватів) кистями (частинами передпліччя) з ножем, оскільки це може призвести до травмування військовослужбовців, які захищаються. Крім цього, нами встановлено, що методика проведення підготовчої частини практичного заняття з рукопашного бою військовослужбовців армії США не повною мірою забезпечує ефективне та без травматичне відпрацювання навчальних завдань, передбачених основною частиною заняття, що підтверджується наявним арсеналом фізичних вправ, викладених у зазначеному стандарті, та власним досвідом участі у сумісних тренуваннях в системі бойової підготовки військовослужбовців НГУ.

Третій етап дослідження (квітень-травень 2020 р.) був присвячений моніторингу науково-методичної літератури у напрямі розроблення сучасних педагогічних моделей формування готовності фахівців до професійної діяльності.

Для подальшого коректного формування отриманих результатів, слід охарактеризувати поняття «підготовка». Цей термін, як зазначає Гавриш I.В., взаємопов'язаний із фаховою освітою та грунтується на концепції безперервного навчання, збагачує поняття готовності; підготовка до професії розглядається як процес формування готовності до неї, а готовність - саме як результат професійної підготовки [25]. У свою чергу, професійна підготовка це система навчання, яка забезпечує формування необхідних компетентностей, потрібних для здійснення певної діяльності 3 метою здобуття певної кваліфікації за конкретною професійною спеціалізацією.

Таким чином, поняття «готовність» є станом готового, а «готовий», згідно 3 термінологією, наведеною у довідковій літературі, це той, хто зробив необхідне приготування до чого-небудь; перебуває у стані, близькому до чогонебудь; заздалегідь продуманий, складений, підготовлений; набув досвіду, уже склався, досяг високої майстерності [26 с. 257]. Готовність індивіда до професійної діяльності досліджували такі вчені як: Бевз А.А., Демченко А.В., Касярум К.В., Кондрашова Л.В., Максименко С.Д., Москальов М.В., Нєпіна Г.В., Пелех О.М., Скоробогат О.М., Сосновський Б.О., Ягупов В.В. та інші.

Заслуговує уваги те, що готовність термінологічно $\mathrm{i}$ фактично $\epsilon$ компетентність (Кловак Г.Т.). Більш цього, готовність залежить від сформованих компетентностей особистості, які необхідні для iї успішної діяльності (Кубіцький С.О.). Певним чином, якщо ведеться дискусія стосовно готовності здобувачів освіти до майбутньої діяльності, то в процесі іiі формування важливу роль відіграє педагогічний вплив (Абдуліна О.А., Демченко О.П., Долинська Л.В., Крутецький В.А., Кузьміна Н.В., Максименко С.Д., Недбай М.П., Пелех О.М., Старчук О.О., Яценко Т.С.). Важливим є й те, що готовність особистості може бути сформована лише за умови, що особистість має чітке уявлення про зміст і структуру діяльності, та за розуміння того, що іiі якості та сформовані компетентності будуть відповідати вимогам 
даної діяльності (Балендр А.В., Бевз А.А., Богданюк О.Д., Головань М.С., Карамушка Л.М., Карпенко М.М., Кловак Г.Т., Кубіцький С.О., Максименко С.Д., Недбай М.П., Пелех О.М., Пономаренко Ю.В., Родигіна І.В., Старчук О.О., Трубачова С.С., Тищенко М.А., Уліч В.Л.).

Під час дослідження структури готовності майбутніх офіцерів ЗСУ та НГУ до виконання завдань за призначенням встановлено, що до основних структурних елементів готовності військовослужбовців Ягупов В.В. [27] відносить, по-перше, мотиваційний, що включає прагнення подолання труднощів майбутнього бою та розуміння необхідності їх подолання, оцінювання своїх можливостей щодо управління психічними станами та діями на основі накопиченого досвіду; по-друге, пізнавальний, який забезпечується необхідним обсягом певної інформації, що потрібна для цілеспрямованої діяльності в екстремальних умовах бойових дій; по-трете, емоційний, який базується на переживанні почуття впевненості або сумніву у своїй готовності до подолання труднощів сучасного бою, умінні керувати своїми емоційновольовими процесами в екстремальних умовах; та, наприкінці, по-четверте, вольовий, що забезпечує військовослужбовцям можливість подолання складнощів бойових дій.

Третій, заключний, етап наших досліджень було присвячено визначенню основних компонентів майбутньої змістово-функціональної моделі рукопашної підготовки курсанток ВВНЗ у системі професійної освіти. Аналіз результатів досліджень в обраному нами напрямі - військово-професійній діяльності курсанток ВВНЗ - дозволяє виділити в їі структурі ряд компонентів, які $\epsilon$ спільними (табл. 3).

Таблиця 3

\section{Аналіз виділення компонентів у структурі готовності майбутніх офіщерів (курсанток ВВНЗ) до військово-професійної діяльності}

\begin{tabular}{|c|c|c|c|c|}
\hline \multirow{2}{*}{ Учений } & \multicolumn{4}{|c|}{ Компонент } \\
\cline { 2 - 5 } & І компонент & IІ компонент & II компонент & IV компонет \\
\hline 1 & 2 & 3 & 4 & 5 \\
\hline Галімов А.В. & $\begin{array}{c}\text { ціннісно- } \\
\text { орієнтаційний }\end{array}$ & $\begin{array}{c}\text { інформаційно- } \\
\text { змістовий }\end{array}$ & $\begin{array}{c}\text { діяльнісно- } \\
\text { технологічний }\end{array}$ & $\begin{array}{c}\text { узагальнено- } \\
\text { прогностичний }\end{array}$ \\
\hline Кубіцький С.О. & $\begin{array}{c}\text { ціннісно- } \\
\text { мотиваційний }\end{array}$ & когнітивний & практичний & оцінний \\
\hline Маріонда І.І. & змістово-цільовий & мотиваційний & $\begin{array}{c}\text { організаційно- } \\
\text { дііяльнісний }\end{array}$ & $\begin{array}{c}\text { контрольно- } \\
\text { регульований }\end{array}$ \\
\hline
\end{tabular}

\begin{tabular}{|l|c|c|c|c|}
\hline \multicolumn{1}{|c|}{1} & 2 & 3 & 4 & 5 \\
\hline Павлов Я.В. & мотиваційний & змістовий & аналітико-оцінний & \\
\hline Сіцінський А.С. & мотиваційний & когнітивний & операціональний & $\begin{array}{c}\text { емоційно- } \\
\text { вольовий }\end{array}$ \\
\hline Швець Д.В. & мотиваційний & когнітивний & діяльнісний & рефлексивний \\
\hline
\end{tabular}

Базуючись на вищевикладеному, вважаємо, що структура готовності курсанток до застосування заходів фізичного впливу містить наступні компоненти: 
мотиваційний - розуміння труднощів службово-бойової діяльності та їх подолання, оцінювання своїх можливостей стосовно управління психічним та фізичним станом;

базовий - формування необхідного початкового рівня фізичної та технічної підготовленості з рукопашного бою;

функціональний - формування та розвиток необхідних професійних компетентностей, які потрібні для застосування заходів фізичного впливу (прийомів рукопашного бою) під час виконання завдань за призначенням у різних умовах службово-бойової діяльності;

прикладний - забезпечення розвитку та удосконалення техніко-тактичного арсеналу службово-прикладного рукопашного бою із використанням технічних засобів навчання та практичного досвіду рукопашної підготовки військовослужбовців - представників блоку НАТО;

стресостійкий - формування високої психологічної стійкості (психофізичної готовності) курсанток ВВНЗ 3СУ (військовослужбовців-жінок силових структур та спеціальних служб України) до застосування заходів фізичного впливу в різних умовах службово-бойової діяльності.

Таким чином, майбутня змістово-функціональна модель рукопашної підготовки курсанток ВВНЗ ЗСУ та НГУ повинна містити наступні блоки: цільовий блок (основні структурні елементи: мета, завдання, педагогічні умови, підходи, компоненти готовності), організаційно-змістовий блок (основні структурні елементи: навчально-методичне забезпечення, інтерактивні методи навчання, кадрове забезпечення) та результативно-оціночний блок (основні структурні елементи, а саме, критерії: кваліфікаційні рівні рукопашної підготовки; методики: методи, засоби, способи, форми).

Висновки та перспективи подальших досліджень. У ході дослідження проведено аналіз науково-методичної та спеціальної літератури, включаючи інтернет-джерела, 3 напряму вдосконалення системи рукопашної підготовки представників силових структур та спеціальних служб України та синтезовано основні існуючі на сьогодні уявлення стосовно особливостей спеціальної підготовки у розрізі гендерних особливостей.

Моніторинг діючих нормативно-правових документів і програм підготовки 3 рукопашного бою курсанток ВВНЗ 3СУ та НГУ в системі їх спеціальної фізичної підготовки, свідчить про те, що на сьогодні існуючі законодавчі норми та правила не повною мірою забезпечують готовність майбутніх офіцерів зазначеної категорії до застосування заходів фізичного впливу в різних умовах службово-бойової діяльності та потребують відповідних змін 3 урахуванням наявного бойового досвіду провідних армій світу та вимог сьогодення.

Відповідно до результатів теоретичного аналізу стандарту бойової підготовки військовослужбовців армії США (ТС 3-25.150 «Combatives» [24]) нами визначено ефективний технічний та тактичний арсенал службовоприкладного рукопашного бою, який відсутній в програмах рукопашної підготовки курсанток ВВНЗ НГУ [20] та ЗСУ [21], а саме: тактичні пересування 
у стійці та в положенні лежачи; прийоми самозахисту в положенні лежачи; прийоми визволення від захватів у положенні лежачи; прийоми обеззброєння в положенні лежачи; способи конвоювання супротивника двома та більше військовослужбовцями; тактичні комбінації (зв'язки) у стійці та партері; контрприйоми у стійці та у положенні лежачи. Зазначений вище перелік прийомів техніко-тактичний арсеналу пропонується включити до програми рукопашної підготовки курсанток ВВНЗ 3СУ та НГУ (військовослужбовцівжінок бойових підрозділів зазначених силових структур).

Вважаємо, що під час формування навичок застосування заходів фізичного впливу військовослужбовцями-жінками 3СУ та НГУ (представницями інших силових структур та спеціальних служб України) конче необхідно враховувати фізіологічні, психофізичні та індивідуально-типологічні особливості жіночого організму, що забезпечить розвиток стійких професійних компетентностей (навичок ведення рукопашної сутички у різних умовах службово-бойової діяльності). Отже, маємо передумови вважати, що сформульована мета дослідження та поставлені завдання для ऑiі досягнення реалізовані повною мірою.

Напрями подальших дослідженьпередбачають розроблення та апробацію змістово-функціональної моделі готовності майбутніх офіцерів (курсанток ВВНЗ ЗСУ та НГУ) до застосування заходів фізичного впливу (прийомів рукопашного бою) у різних умовах службово-бойової діяльності.

\section{ЛІТЕРАТУРА}

1. Михонин А. А. Особенности подготовки военнослужащих-женщин / А. А. Михонин, А. О. Цыганок, А. Ю. Буздов. - СПб. : Гуманитарные и общественные науки, 2003. - С. 5659.

2. Романчук C B. Теоретико-методологічні засади фізичної підготовки курсантів військових навчальних закладів сухопутних військ Збройних Сил України : автореф. дис. ... д-ра наук з фіз. виховання і спорту : 24.00.02 / Романчук Сергій Вікторович. - Львів, 2013. $39 \mathrm{c.}$

3. Малолєпший С. Б. Коефіцієнти ефективності застосування заходів фізичного впливу правоохоронцями МВС України / С. Б. Малолєпший, М. Г. Калюжний, О.В.Хацаюк. Харків : Честь і Закон, 2017. - С. 78-84.

4. Картамышев Д. А. Пути совершенствования обучения рукопашному бою в Вооруженных Силах Российской Федерации с учетом опыта подготовки в армиях зарубежных стран : дис. ... канд. пед. наук : 13.00.04 / Картамышев Дмитрий Алексеевич. СПб., 2017. - 177 с.

5. Радченко Ю.А. Рукопашний бій як прикладний вид спорту та частина фізичної підготовки та спорту у Збройних Силах провідних країн світу / Юрій Радченко // Сучасні тенденції та перспективи розвитку фізичної підготовки та спорту Збройних Сил України, правоохоронних органів, рятувальних та інших спеціальних служб на шляху євроатлантичної інтеграції України : мат. Міжнар. наук.-практ. конф. - К. : Навчально-науковий центр фізичної підготовки та спортивно-оздоровчих технологій, 2017. - С. 75-76.

6. Сухорада Г. І. Забезпечення гендерної рівності по відношенню до змісту фізичної підготовки особового складу / Г. І. Сухорада, В. І. Тверитньов, В. Г. Філін. - Актуальні наукові дослідження в сучасному світі. - Переяслав-Хмельницький : 2019. - С. 158-164. 
7. Соколова Е. П. Оптимизация учебных занятий по физической подготовке военнослужащих-женщин : дис. ... канд. пед. наук : 13.00.04 / Соколова Елена Петровна. СПб., 1999. - 187 с.

8. Боярчук О.В. Дослідження взаємозв'язку рівня рухової активності військовослужбовців-жінок та показників фізичної підготовленості, функціонального й психологічного стану / О. В. Боярчук // Молода спортивна наука України : зб. наук. праць 3 галузі фіз. культури та спорту. - Львів, 2009. - Вип. 13, Т. 2. - С. 21-25.

9. Тьорло О. І. Зміни показників спеціальної фізичної підготовленості та фізичної працездатності курсантів-жінок протягом навчального року : монографія / О. І. Тьорло. Львів : ЛДУВС, 2010. - 264 с.

10. Пічугін М.Ф. Фізичне виховання військовослужбовців: навч. посібн. / М. Ф. Пічугін, Г. П. Грибан, В. М. Романчук. - Житомир : ЖВІ НАУ, 2011. - 820 c.

11. Фильгина Е.В. Современные подходы к организации физической подготовки военнослужащих-женщин : мат. Междунар. научн.-метод. конф. / Е. В. Фильгина, Д. Н. Савич. - Могилев : Могилевский институт МВД Республики Беларусь, 2016. - С. 382385.

12. Кириченко О.М. Форми i зміст фізичної підготовки жіноквійськовослужбовців / О. М. Кириченко, Н. Л. Височіна // Олімпійський спорт : історія, проблеми управління та система підготовки спортсменів : мат. між нар. наук.-практ. конф. Дніпро, 2020. - С. 23-27.

13. Кондратьева А.В. Оценка выступления спортсменок-единоборцев при помощи «Критериев успешности» / А. В. Кондратьева // Ученые записки университета имени П. Ф. Лесгафта. - 2013. - № 5. - С. 66-70.

14. Земцова I. I. Вплив комплексів амінокислот на стан психофізіологічних функцій дзюдоїстів високої кваліфікації / I. І. Земцова, 3. А. Мусаханов, Н. Л. Височіна, Л. Г. Станкевич // Молода спортивна наука України : зб. наук. праць з галузі фіз. культури та спорту. - Львів, 2016. - Вип. 16, Т. 1. - С. 70-76.

15. Симакова Е.А. Функциональная подготовка женщин, участвующих в соревнованиях по многоборью тхэквондо / Е. А. Симакова // Ученые записки университета имени П. Ф. Лесгафта. - 2016. - Т. 135, № 5. - С. 202-208.

16. Высочина Н.Л. Влияние волевых качеств личности на эффективность соревновательной деятельности в разных видах спорта / Н. Л. Высочина // Спортивний вісник Придніпров'я. - 2017. - Т. 11, № 2. - С. 50-53.

17. Головащенко Р. В. Корекція параметрів гематологічного гомеостазу при фізичних навантаженнях за допомогою фармакологічних засобів 3 енергетичною спрямованістю дії / Р. В. Головащенко, М.В.Кузьменко, Л. М. Гуніна, О. В. Носач // Український журнал медицини, біології і спорту. - 2019. - Т. 22, вип. 4.- С. 377-384.

18. Хуртенко О.В. Педагогічні умови формування психологічного профілю жінокєдиноборців високої кваліфікації : фах. наук. журн. / [авт. кол. : О.В.Хуртенко, В. В. Білошицький, С. В. Власко та ін.]. - Одеса : Інноваційна педагогіка, 2020. - С. 215-229.

19. Шемчук В.А. Результати визначення професійних компетентностей жінокєдиноборців високої кваліфікації: наук. збірн. / [авт. кол. : В. А.Шемчук, С. М. Дмитренко , В. Б. Климович та ін.]. - Дніпро : Актуальні питання гуманітарних наук, 2020. - С. 118-133.

20. Лещеня С. Інструкція з організації фізичної підготовки в Національній гвардії України: інстр. / С. Лещеня, І. Орленко, А. Мелешко, С. Забродський. - К.: ГУНГУ, 2019. $156 \mathrm{c.}$

21. Тимчасова настанова $з$ фізичної підготовки у Збройних Силах України (НСТ-Т 01.035.0012013 (01)). - Київ : Генеральний штаб ЗСУ (Наказ від 11.02.2014 №35), 2014. - 156 с.

22. Хацаюк О. В. Спеціальна фізична підготовка : роб. прогр. навч. дисц. (галузь знань 25. Воєнні науки, національна безпека, безпека державного кордону) / О. В. Хацаюк. Харків : НАНГУ, 2019. - 56 с. 
23. Романчук С. В. Фізичне виховання та спеціальна фізична підготовка: роб. прог. навч. дисц. (галузь знань 25. Воєнні науки, національна безпека, безпека державного кордону) / С. В. Романчук, М. О. Сна. - Львів : Нац. акад. сух. військ ім. гетьмана Петра Сагайдачного, 2017. - 47 с.

24. Стандарт - TC 3-25.150. [Електронний ресурс] : Combatives // Head quarters Department of the Army, Washington, DC. - 2017. - No. 3-25.150. - 407 с. [Режим доступу до станд.] : http://www.everyspec.com/MIL-STD/.

25. Гавриш I. В. Теоретико-методологічні основи формування готовності майбутніх учителів до інноваційної професійної діяльності : дис. ... д-ра пед. наук : 13.00 .04 / Гавриш Ірина Володимирівна. - Харків, 2006. - 542 с.

26. Великий тлумачний словник української мови (уклад. і гол. ред. В.Т. Бусел). Ірпінь : ВТФ Перун, 2004. - 1440 с.

27. Ягупов В. В. Педагогіка : навч. посібн. для студ. / В. В. Ягупов. - К.: Либідь, 2003. - 560 с.

\section{REFERENCES}

1. Mykhonyn, A. A., Tsuhanok, A. O., Buzdov, A. Yu. (2003). Osobennosty podhotovky voennosluzhashchykh-zhenshchyn [Features of the training of female military personnel]. Humanytarnue y obshchestvennue nauky, 12, 56-59.

2. Romanchuk, S. V. (2013). Teoretyko-metodolohichni zasady fizychnoi pidhotovky kursantiv viiskovykh navchalnykh zakladiv sukhoputnykh viisk Zbroinykh Syl Ukrainy [Theoretical and methodological principles of physical training of cadets of military educational institutions of the land forces of the Armed Forces of Ukraine]. (Abstract of PhD thesis), Lviv.

3. Maloliepshyi, S. B., Kaliuzhnyi, M. H., Khatsaiuk, O. V. (2017). Koefitsiienty efektyvnosti zastosuvannia zakhodiv fizychnoho vplyvu pravookhorontsiamy MVS Ukrainy [Coefficients of efficiency of application of measures of physical influence by militiamen of the Ministry of Internal Affairs of Ukraine]. Chest i Zakon, 1 (60), 78-84.

4. Kartamushev, D. A. (2017). Puty sovershenstvovanyia obuchenyia rukopashnomu boiu v Vooruzhennukh Sylakh Rossyiskoi Federatsyy s uchetom oputa podhotovky $\mathrm{v}$ armyiakh zarubezhnukh stran [Ways to improve the training of hand-to-hand combat in the Armed Forces of the Russian Federation, taking into account the experience of training in the armies of foreign countries]. (Abstract of $\mathrm{PhD}$ thesis), $\mathrm{SPb}$.

5. Radchenko, Yu. A. (2017). Rukopashnyi bii yak prykladnyi vyd sportu ta chastyna fizychnoi pidhotovky ta sportu u Zbroinykh Sylakh providnykh krain svitu [Hand-to-hand combat as an applied sport and part of physical training and sports in the Armed Forces of the world's leading countries]. Navchalno-naukovyi tsentr fizychnoi pidhotovky ta sportyvno-ozdorovchykh tekhnolohii, 75-76.

6. Sukhorada, H. I., Tverytnov, V. I., Filin V. H. (2019). Zabezpechennia hendernoi rivnosti po vidnoshenniu do zmistu fizychnoi pidhotovky osobovoho skladu [Ensuring gender equality in relation to the content of physical training of personnel]. Aktualni naukovi doslidzhennia $\mathrm{v}$ suchasnomu sviti, 158-164.

7. Sokolova, E. P. (1999). Optymyzatsyia uchebnukh zaniatyi po fyzycheskoi podhotovke voennosluzhashchykh-zhenshchyn [Optimization of training sessions for physical training of women servicemen]. (Abstract of $\mathrm{PhD}$ thesis), $\mathrm{SPb}$.

8. Boiarchuk, O. V. (2009). Doslidzhennia vzaiemozviazku rivnia rukhovoi aktyvnosti viiskovosluzhbovtsiv-zhinok ta pokaznykiv fizychnoi pidhotovlenosti, funktsionalnoho $y$ psykholohichnoho stanu[Study of the relationship between the level of motor activity of women servicemen and indicators of physical fitness, functional and psychological condition]. Moloda sportyvna nauka Ukrainy, 13 (T. 2.), 21-25.

9. Torlo, O. I. (2010). Zminy pokaznykiv spetsialnoi fizychnoi pidhotovlenosti ta fizychnoi pratsezdatnosti kursantiv-zhinok protiahom navchalnoho roku [Changes in indicators of special physical fitness and physical fitness of female cadets during the academic year]. L.: LDUVS, 264. 
10. Pichuhin, M. F., Hryban, H. P., Romanchuk, V. M. (2011). Fizychne vykhovannia viiskovosluzhbovtsiv [Physical education of servicemen]. Zh.:ZhVI NAU, 820.

11. Fylhyna, E. V. (2016). Sovremennue podkhodu k orhanyzatsyy fyzycheskoi podhotovky voennosluzhashchykh-zhenshchyn[Modern approaches to the organization of physical training of women servicemen]. Mohylevskyi ynstytut MVD Respublyky Belarus, 382-385.

12. Kyrychenko, O. M., Vysochina, N. L. (2020). Formy i zmist fizychnoi pidhotovky zhinok-viiskovosluzhbovtsiv[Forms and content of physical training of women servicemen]. Olimpiiskyi sport : istoriia, problemy upravlinnia ta systema pidhotovky sportsmeniv, 23-27.

13. Kondrateva, A. V. (2013). Otsenka vustuplenyia sportsmenok-edynobortsev pry pomoshchy «Kryteryev uspeshnosty» [Evaluation of martial arts athletes using «Success Criteria»]. Uchenue zapysky unyversyteta ymeny P.F. Leshafta, 5, 66-70.

14. Zemtsova, I. I., Musakhanov, Z. A., Vysochina, N. L., Stankevych, L. H. (2016). Vplyv kompleksiv aminokyslot na stan psykhofiziolohichnykh funktsii dziudoistiv vysokoi kvalifikatsii [Influence of amino acid complexes on the state of psychophysiological functions of highly qualified judokas]. Moloda sportyvna nauka Ukrainy, 16 (T. 1.), 70-76.

15. Symakova, E. A. (2016). Funktsyonalnaia podhotovka zhenshchyn, uchastvuiushchykh v sorevnovanyiakh po mnohoboriu tkhэkvondo [Functional training of women participating in taekwondo all-around competitions]. Uchenue zapysky unyversyteta ymeny P.F. Leshafta, 5 (T. 135.), 202-208.

16. Vusochyna, N. L. (2017). Vlyianye volevukh kachestv lychnosty na effektyvnost sorevnovatelnoi deiatelnosty $\mathrm{v}$ raznukh vydakh sporta [The influence of strong-willed personality traits on the effectiveness of competitive activities in different sports]. Sportyvnyi visnyk Prydniprovia, 2 (T. 11.), 50-53.

17. Holovashchenko, R. V., Kuzmenko, M. V., Hunina, L. M., Nosach, O. V. (2019). Korektsiia parametriv hematolohichnoho homeostazu pry fizychnykh navantazhenniakh za dopomohoiu farmakolohichnykh zasobiv $\mathrm{z}$ enerhetychnoiu spriamovanistiu dii [Correction of parameters of hematological homeostasis during exercise with the help of pharmacological agents with energy orientation of action]. Ukrainskyi zhurnal medytsyny, biolohii i sportu, 4 (T. 22.), 377384.

18. Khurtenko, O. V., Biloshytskyi, V. V., Vlasko, C. V. (2020). Pedahohichni umovy formuvannia psykholohichnoho profiliu zhinok-yedynobortsiv vysokoi kvalifikatsii [Pedagogical conditions for the formation of the psychological profile of highly qualified single wrestlers]. Innovatsiina pedahohika, 215-229.

19. Shemchuk, V. A., Dmytrenko,S. M., Klymovych,V. B. (2020).Rezultaty vyznachennia profesiinykh kompetentnostei zhinok-yedynobortsiv vysokoi kvalifikatsii[The results of determining the professional competencies of highly qualified single wrestlers]. Aktualni pytannia humanitarnykh nauk, 118-133.

20. Leshchenia, S., Orlenko, I, Meleshko, A., ZabrodskyiS. (2019). Instruktsiia z orhanizatsii fizychnoi pidhotovky v Natsionalnii hvardii Ukrainy [Instruction on the organization of physical training in the National Guard of Ukraine]. K. : HUNHU, 156.

21. Tymchasova nastanova $\mathrm{z}$ fizychnoi pidhotovky u Zbroinykh Sylakh Ukrainy (NSTT 01.035.001-2013 (01))[Temporary guidelines for physical training in the Armed Forces of Ukraine (NST-T 01.035.001-2013 (01))]. Heneralnyi shtab ZSU. Nakaz vid 11.02.2014 №35, 156.

22. Khatsaiuk, O. V. (2019). Spetsialna fizychna pidhotovka [Special physical training]. Kh.:NANHU, 56.

23. Romanchuk, S. V., Yena, M. O. (2017). Fizychne vykhovannia ta spetsialna fizychna pidhotovka [Special physical training]. Lv.:Nats. akad. sukh. viisk im. hetmana Petra Sahaidachnoho, 47.

24. Combatives (Training Circular TC 3-25.150) // Head quarters Department of the Army, Washington, DC. - 2017. - No. 3-25.150. - 407 p. Military Standards are available online athttp://www.everyspec.com/MIL-STD/.(in English). 
25. Havrysh, I. V. (2006). Teoretyko-metodolohichni osnovy formuvannia hotovnosti maibutnikh uchyteliv do innovatsiinoi profesiinoi diialnosti [Theoretical and methodological bases of formation of readiness of future teachers for innovative professional activity]. (Abstract of PhD thesis), Kharkiv.

26. Busel, V.T. (2004). Velykyi tlumachnyi slovnyk ukrainskoi movy [Large explanatory dictionary of the Ukrainian language]. Irpin.:VTF Perun, 1440.

27. Yahupov, V.V. (2003). Pedahohika [Pedagogy]. K.:Lybid, 560.

\section{PЕЗЮМЕ}

Надежда Высочина, доктор наук по физическому воспитанию и спорту Учебно-научный институт физической культуры и спортивно-оздоровительных технологий

Национального университета обороны Украины имени Ивана Черняховского

Лариса Гунина,

доктор биологических наук, профессор Олимпийский институт Национального университета физического воспитания и спорта Украины

Лидия Котляренко, доктор биологических наук, профессор Учебно-научный институт физической культуры и спортивно-оздоровительных технологий

Национального университета обороны Украины имени Ивана Черняховского

Ольга Малахова,

Учебно-научный институт физической культуры и спортивно-оздоровительных технологий Национального университета обороны Украины имени Ивана Черняховского

Елена Кириченко, Войсковая часть А0136 Вооруженных Сил Украины

\section{Теоретико-методические предпосылки формирования системы рукопашной подготовки военнослужащих-женщин с учетом опыта стран блока НАТО}

Рассмотрена актуальная проблема формирования военно-прикладных навыков рукопашного боя военнослужаших-женщин (на примере курсанток старших курсов НАНГУ). В соответствии $c$ мониторингом научно-методической $u$ специальной литературы в избранном направлении исследования определень основные блоки будущей содержательно-функииональной модели рукопашной подготовки курсанток в системе их профессионального образования. Считаем, что при формировании навыков применения мер физического воздействия военнослужащчими-женщчинами ВСУ и НГУ необходимо учитывать физиологические, психофизические и индивидуально-типологические особенности женского организма, что обеспечит развитие устойчивых профессиональных компетенций (навыков ведения рукопашной схватки).

Ключевые слова: военнослужащие-женщины; будущие офищеры; профессиональная подготовка; система рукопашной подготовки; специальная физическая подготовка; технический арсенал; новые стандарты. 
NadiyaVysochina, doctor of Physical Trainingand Sport Educational and Scientific Institute of Physical Culture and Sports and Health Technologies of the National Defence University of Ukraine named after Ivan Cherniakhovskyi

Larisa Gunina,

doctor Biological Science, professor Olympic Institute of the National University of Physical Education and Sport of Ukraine

LidiyaKotlyarenko,

doctor Biological Science, professor

Educational and Scientific Institute of Physical Culture and Sports and Health

Technologies of the National Defence University of Ukraine named after Ivan Cherniakhovskyi

Olga Malahova,

Educational and Scientific Institute of Physical Culture and Sports and Health Technologies of the National Defence University of Ukraine named after Ivan Cherniakhovskyi

Olena Kyrychenko, Military unit A0136 of the Armed Forces of Ukraine

\section{Theoretical and Methodological prerequisites for the formation of a System of Hand-to- hand combat training of women Servicemen, taking into account the experience of NATO bloc countries}

Introduction.The use of the latest pedagogical technologies during practical hand-to-hand combat (HHC) classes with future female officers who associate their activities with service in the Armed Forces of Ukraine (AFU) and the National Guard of Ukraine (NGU) during their professional development will ensureacquisition of the necessary level of readiness for performance of tasks on purpose and is an actual direction of scientific researches.

Purpose.The main purpose of this work is to build approaches to the formation of a system for determining the basic components of HHC combat skills of cadets (women) of higher military educational institutions (HMEI) of Ukrainian security forces in the system of their vocational education.

Methods.Analysis and generalization of the results of special educational-methodical and scientific-methodical literature and relevant areas of research of Internet resources.

Results.As a result of the research the main components of the future semantic-functional model of hand-to-hand training of cadets of HMEI are determined.It is established that the structure of readiness of cadets (women) for application of receptions of HHC contains the following components: motivational, basic, functional, applied, stress-resistant. The future contentfunctional model should contain the following blocks: target block, organizational-content block and result-evaluation block.

Originality. The scientific novelty of the expected results lies in the fact that it is planned to identify, theoretically substantiate and experimentally test the pedagogical conditions for the 
formation of HMEI cadets (women) readiness to use HHC techniques in different conditions of service and combat activities. The practical significance of the expected results is to increase the professional competencies of cadets (HHC military applied skills), which will ensure the effective performance of their assigned tasks.

Conclusion.According to the results of the theoretical analysis of the standard of combat training of US servicemen (TC 3-25.150 «Combatives»), we have identified an effective technical and tactical arsenal of the HHC, which is absent in the hand-to-hand training programs of HMEI $N G U$ and $A F U$ cadets.

Key words: female servicemen; future officers; professional training; hand-to-hand combat training system; special physical training; technical arsenal; new standards. 